\title{
Gegevensperceptie en financiële functie
}

\section{A.M.M. Blommaert}

Accountants besteden een steeds groter deel van hun werkzaamheden aan de interne berichtgeving (management accounting). Naast aandacht voor dit vakgebied in hun opleiding vereist dit een andere attitude en afweging ten aanzien van gegevenskwaliteiten zoals betrouwbaarheid en relevantie. Wanneer interne berichtgevingssystemen hoofdzakelijk worden opgezet vanuit aspecten als 'controleerbaarheid' en 'verifieerbaarheid', dan zijn vele van deze systemen tot mislukken gedoemd, dat wil zeggen: in vele gevallen zal sprake zijn van 'voorspelbare irrelevantie'. Het prospectieve element in de interne berichtgeving en genoemde gegevenskarakteristieken zijn immers niet of slechts ten dele verenigbaar.

Dit artikel is het verslag van een onderzoek waarin wordt aangetoond dat de in bovenstaand verband noodzakelijke gegevens-perceptionele aanpassing van accountants respectievelijk controllers nog slechts beperkt (te beperkt?) tot ontwikkeling is gekomen.

\section{Inleiding}

De kwaliteit van de intern financieel-administratieve dienstverlening, hierna aangeduid als management accounting, staat ter discussie (zie bijvoorbeeld Goldratt en Fox, 1991:34 en Mednick, 1992:557). De behoefte aan een conceptual framework wordt hiermee steeds sterker. Een conceptual framework kan worden gezien als 'de verzameling van algemeen aanvaarde uitgangspunten voor de beoefening van een vak of tak van wetenschap'. Een conceptual framework, zijnde een beschrijving van een doel-middelen relatie, kan de theorievorming stimuleren en kan als referentie dienst doen bij het opsporen van problemen in de huidige in gebruik zijnde systemen. In de externe berichtgeving (financial accounting) heeft men inmiddels zo'n conceptual framework ontwikkeld. ${ }^{2}$ Doeleinden, te verstrekken overzichten, kwalitatieve gegevens-eisen en te volgen postulaten en principes zijn in dit conceptual framework vastgelegd.

Ook Anthony (1991) signaleert het gebrek aan een (bevredigend) conceptual framework voor de management accounting.

'We don't have the accounting concepts we need' (1991:11)

Anthony vergelijkt de behoefte aan een conceptual framework met de behoefte van een land aan een grondwet als basis voor de ontwikkeling van wetten en jurisprudentie (alhoewel het conceptual framework niet de juridische status van grondwet bezit).

Men kan de vraag aan de orde stellen in hoeverre de management accounting zinvol gebruik kan maken van het voor de financial accounting ontwikkelde conceptual framework voor wat betreft de hierin onderscheiden kwalitatieve gegevenseisen (gegevenskenmerken). In dit artikel wordt verslag gedaan van een onderzoek te dien aanzien. De hierbij aangehouden hypothese is:

Het 'conceptual framework' voor de financial accounting is voor wat betreft de hierin onderscheiden gegevenskenmerken tevens bruikbaar voor de management accounting, met

A.M.M. Blommaent is docent Interne Berichtgeving aan de Economische Faculteit van de Rijksuniversiteit Limburg 
dien verstande dat in de management accounting ten aanzien van de onderscheiden gegevenskenmerken significant afwijkende belangrijkheidscoëfficiënten gelden.

Voor de validatie van deze hypothese is in april 1992 een schriftelijke enquête uitgevoerd onder bij het NIVRA ingeschreven 240 registeraccountants alsmede bij 120 (register)controllers. In dit artikel worden de resultaten van deze enquête samengevat. De integrale tekst van het enquêteformulier is als bijlage bij dit artikel gevoegd (zie bijlage 2).

\section{Populaties, response en statistische verwerking van de gegevens}

In totaal werden 240 enquêtes verzonden aan bij het NIvRA ingeschreven accountants (zo'n 3\% van het totaal) en 120 enquêtes aan (register)controllers (dit aantal was het totale aantal afgestudeerde controllers per dat moment). ${ }^{3}$ Op het totaal van 360 verzonden formulieren bedroeg de response 137 . Dit is $38 \%$. Per vraag verschilt de bruikbare respons enigszins.

Bij de beoordeling van het mogelijke gebruik van het financial accounting conceptual framework voor zover dit de gegevenskenmerken betreft - in de management accounting, zijn met name de vragen 10 en 11 van het enquête-formulier van belang. De in deze vragen opgenomen gegevenskarakteristieken zijn ontleend aan het IASC conceptual framework. Voor de beantwoording van beide vragen is een 5 -punts Likert-schaal opgesteld, aflopend van bijzonder belangrijk tot volstrekt onbelangrijk. Ook voor de beantwoording van een aantal overige vragen is van een vijfpunts Likert-schaal gebruik gemaakt.

Ten einde de verschillen in de antwoorden per groep te kunnen beoordelen, is de non-parametrische Wilcoxon-Mann-Whitney test uitgevoerd. De two-sample Kolmogorov-Smirnov test (KStest) is als controlerende test uitgevoerd. Als significantienorm is steeds $1 \%$ aangehouden.

\section{Enquête-resultaten; profielschets van de respondenten: accountants en controllers}

De enquête-resultaten bevestigen dat accountants veel meer werkzaam zijn op het gebied van de externe berichtgeving dan controllers die meer op het gebied van de interne berichtgeving hun emplooi vinden. Op een Likert-schaal van 1-5 van volledig financial accounting naar volledig management accounting bedroeg de cumulatieve relatieve frequentie bij de RA's in de eerste drie schaaleenheden $68 \%$ terwijl dit voor de RC's slechts $19 \%$ bedroeg. De postdoctorale accountants (= groep RA-PD) neigen in dit verband iets meer naar de management accounting dan hun buiten-universitaire NIvRA-collegae (=groep RANV): $75 \%$ respectievelijk $65 \%$ cumulatieve frequentie in de eerste drie schaaleenheden). Dit beeld wordt min of meer bevestigd in de gemiddelde verdeling qua tijd van de huidige werkzaamheden. Deze verdeling is in tabel 1 weergegeven (afgerond op hele procenten).

Tabel 1: Overzicht tijdsbesteding accountants/controllers per april 1992

\begin{tabular}{lllll}
\hline groep & $\begin{array}{l}\text { aantal } \\
\text { respon- } \\
\text { denten }\end{array}$ & $\begin{array}{l}\text { gemiddelde huidige } \\
\text { tijdsbesteding in } \%\end{array}$ & \\
\hline & & controle & advies & management \\
RA-NV & 58 & 37 & 37 & 26 \\
RA-PD & 30 & 21 & 50 & 30 \\
RC & 41 & 14 & 62 & 24 \\
Totaal & 129 & & & \\
\hline
\end{tabular}

In de tijd zien we dat het controlewerk voor accountants, dit is het in opdracht van een bepaalde partij toevoegen van geloofwaardigheid aan door derden beschikbaar gestelde gegevens, dalende is. Maakten de controlewerkzaamheden voor accountants bijvoorbeeld drie jaar geleden nog gemiddeld $42 \%$ van hun werk uit (bij 35\% advieswerk), tegenwoordig is dit gemiddeld nog slechts $32 \%$ (bij $42 \%$ advieswerk). ${ }^{4}$ Deze ontwikkeling is voor de onderscheiden groepen nagenoeg gelijk.

Ten aanzien van de functie-inhoud (financial 
accounting/management accounting) bedroeg de cumulatieve relatieve frequentie voor de categorieën $4+5$ op de Likert-schaal (nagenoeg volledig c.q. volledig management accounting) voor de groepen RA's respectievelijk 35\% en 25\%. Deze resultaten maken duidelijk dat een substantieel deel van de werkzaamheden van accountants op het gebied van de interne berichtgeving ligt. Voor de groep RC bedroeg genoemde frequentie $82 \%$.

Het overgrote deel van de respondent-accountants was werkzaam op een accountantskantoor $(45 \%)$ respectievelijk in het (overige) bedrijfsleven $(40 \%$ ) (zie vraag $4 \mathrm{~A}$ ). Van de controllers was $83 \%$ werkzaam in het (overige) bedrijfsleven. Het restant was voor beide groepen gelijk verdeeld tussen non-profit sector en overheid.

Als belangrijkste functie van management accounting kwam naar voor het ondersteunen van beslissingsprocessen (planning). In totaal gaf $35 \%$ van de respondenten deze functie de hoogste prioriteit. Bovendien gaven 10\% respectievelijk $18 \%$ van de respondenten aan dat gegevens voor de ondersteuning en beheersing respectievelijk voor de ondersteuning en beheersing en interne verantwoording door de management accounting dienen te worden verstrekt. In geval van een nationaal georiënteerd bedrijf wordt de verantwoordingsfunctie van management accounting aanzienlijk belangrijker geacht dan in geval van een internationaal georiënteerd bedrijf waarbij de component 'control' meer accent heeft. Respondenten die aangaven meer in het vlak van de financial accounting werkzaam te zijn, waardeerden de component 'verantwoording' substantieel hoger dan hun collegae (driekwart van de respondenten die bij vraag 5 de schalen 1 respectievelijk 2 hadden aangekruist, vonden de verantwoordingsfunctie van accounting primair).

\section{Hypothese-testing}

De in de inleiding vervatte hypothese valt feitelijk uiteen in een tweetal vragen:

(1) Is het conceptual framework zoals ontwikkeld voor de financial accounting en voor zover dit de gegevenskenmerken betreft, ook bruikbaar voor de management accounting?

(2) In hoeverre worden in de management accounting aan de onderscheiden gegevenskenmerken andere belangrijkheidscoëfficiënten toegekend dan in de financial accounting?

Antwoord op de eerste vraag kan worden verkregen door na te gaan in hoeverre er bij specialisten in de management accounting de behoefte bestaat gegevenskenmerken toe te voegen aan het raamwerk van gegevenskenmerken zoals dat bestaat in de financial accounting.

Noch van de registeraccountants die een financial accountingfunctie vervulden noch van de registeraccountants die een soort tussenpositie innamen in financial accounting en management accounting gaf enig respondent aan een gegevenskenmerk te willen toevoegen. Van de registeraccountants met een management accountingfunctie gaf slechts één respondent te kennen gegevenskenmerken te willen toevoegen ('relevantie' en 'begrijpbaarheid'). Van de controllers in een management accountingfunctie gaven 5 respondenten aan een aanvullend gegevenskenmerk te willen opnemen: verantwoording afleggen, efficiency, informatiewaarde, begrijpelijkheid en strategische aspecten. Van de controllers die een middenpositie innamen, gaf niemand aan behoefte te hebben de vermelde gegevenskenmerken uit te breiden. Bij de controllers met een hoofdzakelijk financial accounting getinte functie gaf één respondent aan het aspect 'volledigheid' te willen toevoegen. Uit deze inventarisatie kan voorzichtig worden geconcludeerd dat het financial accountingraamwerk van gegevenskenmerken zoals voorgesteld door het IASC ook goede diensten kan bewijzen in de management accounting. Dit geldt te meer omdat een aantal van de genoemde aanvullende gegevenskenmerken (zoals efficiency, begrijpelijkheid en informatiewaarde) wordt afgedekt in de algemene gegevenskarakteristieken en voorwaarden zoals die in het IASC-model zijn genoemd (met name 'benefits > costs' en 'understandability (als bepalend voor 'decision usefullness'). Bovendien is het aspect 'volledigheid' een onderdeel van het in het raam- 
werk als 'representational faithfulness' aangeduide kenmerk.

Vervolgens is nagegaan of in de management accounting de onderscheiden gegevenskenmerken anders worden gewogen dan in de financial accounting.

Voor het vergelijken van de mate waarin men in het algemeen de basiskenmerken relevantie c.q. betrouwbaarheid van belang acht, is voor de totale steekproefpopulatie een gemiddelde score berekend voor beide gegevenskenmerken. Hierbij is een antwoord in categorie 1 op de vijfpuntsrelevantieschaal met 5 punten gewaardeerd, een antwoord in categorie 2 is gewaardeerd met 4 punten, enzovoort. Voor het aspect betrouwbaarheid is op soortgelijke wijze een gemiddelde score bepaald. Langs deze weg kan op basis van de enquête-resultaten het volgende worden vastgesteld (zie tabel 2):

Tabel 2: Relevantie versus betrouwbaarheid (aantal respondenten 127)

\begin{tabular}{ll}
\hline aspect & gemiddelde score \\
\hline relevantie & 4,44 \\
betrouwbaarheid & 4,27 \\
\hline
\end{tabular}

De gemiddelde ratio 'relevantie/betrouwbaarheid' ligt derhalve op $4,44 / 4,27=1,04$. Interessant is het antwoord op de vraag of deze ratio anders ligt per bedrijfssector, per bedrijfsoriëntatie, per opleiding, duur van het dienstverband en - hetgeen centraal staat in dit onderzoek - per functie-inhoud (financial accounting/management accounting).

Alhoewel de non-profit sector een opvallend hoge ratio gaf (in casu 1,16), is deze uitkomst niet dusdanig dat van een significant verschil kan worden gesproken.

In het internationaal georiënteerd bedrijf (dat wil zeggen, meer dan de helft van de omzet wordt in het buitenland gerealiseerd) ligt de verhouding 'relevantie/betrouwbaarheid' op 1,07, voor het nationaal georiënteerd bedrijf is deze verhouding 1,03 . Geen grote verschillen derhalve in vergelijking met de gemiddelde steekproefscore.

Voor wat betreft de relatie van de genoemde ratio en de duur van het functieverband geldt dat naarmate het functieverband langer heeft geduurd, de ratio oploopt (doch niet significant): van 1.00 tot 1.05 tot 1.07 .

Bij de registeraccountants ligt de ratio relevantie/betrouwbaarheid op 1.15 terwijl deze bij de controllers ligt op 1.00. Gezien de management accountingfunctie van controllers zou men een geheel andere verhouding verwachten! Wanneer men evenwel de relatieve frequentie-opbouw meeneemt, ontstaat een iets ander en daarmee meer in de lijn van de verwachtingen liggend beeld. Op de 5-punts Likert-schaal antwoordt in de categorieën $1+2$ voor relevantie $88 \%$ van alle ondervraagde accountants terwijl in deze categorieën $98 \%$ van de controllers antwoordt. Voor het aspect betrouwbaarheid ligt dit op respectievelijk $92 \%$ en $74 \%$. Hiermee wordt de vermoede voorkeur van accountants voor betrouwbaarheid boven relevantie bevestigd. Bij controllers ligt dit omgekeerd. De ten opzichte van de controllers relatief hoge ratio 'relevantie/betrouwbaarheid' voor accountants kan met name worden verklaard uit het feit dat vele accountants een management accountingfunctie en dus een met een controller vergelijkbare functie vervullen. De invloed van met name deze factor wordt hierna nader geanalyseerd.

De achtergrond van de accountant (al dan niet universitair) is van geen materiële betekenis in de perceptie relevantie-betrouwbaarheid (de betreffende ratio was in deze gevallen respectievelijk 1.03 en 1.00 ).

Voor wat betreft de relatie tussen de aard van de accountingfunctie en de mate waarin het aspect relevantie respectievelijk betrouwbaarheid belangrijk wordt geacht, kan het volgende worden opgemerkt. Van alle respondenten die een management accountingfunctie vervullen (hiertoe zijn beschouwd alle respondenten die in de categorieën 4 en 5 op vraag 5 hebben geantwoord), bedraagt de ratio 'relevantie/betrouwbaarheid' 1.11. Bij de respondenten die een financial 
accountingfunctie vervullen ligt deze ratio 0.97. Derhalve is de omvang van de ratio in belangrijke mate afhankelijk van de inhoud van de accountingfunctie. Wanneer men voor beide functies en gegevenscriteria uitsluitend de categorieën 1 en 2 in de schaal van bijzonder belangrijk naar volstrekt onbelangrijk in ogenschouw neemt (ten einde eventuele mis-interpretaties uit te schakelen), wordt dit beeld verder versterkt. De ratio relevantie/betrouwbaarheid ligt in dit geval bij de management accountants op 1,28 en bij de financial accountants op 0,94 . Ook in de opbouw van de verdeling rond het gemiddelde is een voorkeur waarneembaar van management accountants/controllers voor relevantie boven betrouwbaarheid. Maar gezien de prospectieve inhoud van de taken en functies van de management accountant/controller ten opzichte van de (controlerend) accountant (zie Bromwich, 1988:26; Wallage en Tijhuis, 1992:11) zou men wellicht bij controllers een grotere tolerantie ten aanzien van de betrouwbaarheid van de gegevens verwachten en een dito hogere ratio relevantie/betrouwbaarheid. ${ }^{5}$

In het algemeen waarderen controllers het aspect 'relevantie' hoger dan registeraccountants (controlerend accountants en management accountants). De gemiddelde score bedroeg respectievelijk 4,59 en 4,37 . Het verschil in spreiding in deze waarderingen was niet significant, alhoewel aanzienlijk ( $p$-waarde 3,155\%).

Voor wat betreft het aspect 'betrouwbaarheid' kan worden gesteld dat controllers over het algemeen minder belang hechten aan 'betrouwbaarheid' dan registeraccountants. Bij een gemiddelde score van respectievelijk 3,54 en 4,39 is het geconstateerde verschil in spreiding significant ( $p$-waarde 0,65\%). Overigens werd deze significantie niet door de KS-test bevestigd.

Wanneer de functie-inhoud expliciet wordt meegewogen in het onderzoek, kan worden gesteld dat er een belangrijk verschil bestaat tussen de waardering van financial accountants ten opzichte van management accountants (inclusief controllers) voor wat betreft het aspect 'relevantie'. Financial accountants waarderen dit aspect gemiddeld op 4,19 terwijl de gemiddelde score bij management accountants 4,57 bedraagt. Alhoewel niet significant bij de aangehouden $1 \%$ norm kan er wel worden gesproken van een belangrijk verschil in spreiding ( $p$-waarde 1,275\%). Ook dit verschil in spreiding werd niet in de zelfde mate door de KS-test bevestigd.

De beoordeling van het aspect 'betrouwbaarheid' door de hiervoor genoemde twee groepen bleek niet significant afhankelijk te zijn van de functieinhoud (gemiddelde scores respectievelijk 4,33 en 4,11 ) en ook de spreiding rond deze waarden bij beide groepen bleek niet significant te verschillen (p-waarde 12,88\%).

De verschillen in waarderingen ten aanzien van de deelaspecten van 'relevantie' en 'betrouwbaarheid' (zie voor deze aspecten bijlage 1) alsmede indicaties van de verschillen in de spreiding in de scoreverzamelingen van financial accountants ten opzichte van management accountants (inclusief controllers), zijn in bijlage 3 in een tabel samengebracht.

Alhoewel de verschillen in gemiddelde scores niet groot zijn, zijn opvallend de grote verschillen in spreiding bij de deelaspecten 'controleerbaarheid' en 'externe validiteit'. Deze zijn (nagenoeg) significant te noemen (de KS-test bevestigde deze significanties evenwel niet).

Concluderend moet worden gesteld dat het aspect 'relevantie' alsmede de deelaspecten waaruit dit is opgebouwd, onvoldoende (dit is niet-significant) in de perceptie van de functionarissen die een management accountingfunctie vervullen tot uitdrukking komen. Een mogelijke verklaring voor deze bevinding is dat registeraccountants die een management accountingfunctie vervullen zich maar moeilijk kunnen losmaken van de in hun opleiding zo benadrukte aspecten als 'betrouwbaarheid', 'neutraliteit' en 'controleerbaarheid'. In een management accountingfunctie die feitelijk prospectief is gericht, zal men bereid moeten zijn op deze criteria in te leveren ten gunste van de relevantie. Maar ook controllers kiezen niet eenduidig voor relevantie. Deels zou dit kunnen worden verklaard uit het feit dat de oplei- 
ders van controllers voor een niet onbelangrijk deel zelf accountant zijn c.q. dat de opleiding voor controllers nog te sterk op het werk van de controlerend accountant is gericht. ${ }^{6}$

Bij vraag 11 van het enquête-formulier is ten behoeve van het testen van de onderlinge consistentie van de antwoorden een aantal correlatietests uitgevoerd. Hiertoe is de Spearman rankorder correlatie-coëfficiënt berekend waarbij de Kendall correlatie-coëfficiënt steeds als controlerende variabele is bepaald. Bij de beoordeling van de significantie van de correlaties zijn eenzijdige tests uitgevoerd.

De correlatie tussen de waarderingen van de aspecten 'relevantie' en 'voorspellende waarde' bleek vrij groot. De significantiegrens (gecorrigeerd voor gelijke rangordes) bedroeg $2,185 \%$.

De correlatie van de waarderingen van de aspecten 'relevantie' en 'feedback waarde' was opvallend laag (een significantiegrens van 41,125\%) en bovendien negatief! (Rho en Tau gecorrigeerd voor gelijke rangordes respectievelijk $-0,2$ en $-0,18)$. Daarentegen was de correlatie tussen de waarderingen van de aspecten 'relevantie' en 'tijdigheid' weer groter en positief, maar bij een significantienorm van $1 \%$ niet significant (significantiegrens $7,78 \%$ ).

De correlatie tussen de waarderingen van de aspecten 'neutraliteit', 'controleerbaarheid' en 'externe validiteit' met hun moederkenmerk 'betrouwbaarheid' was hoog en positief (significantiegrens respectievelijk $1,215 \%, 0,05 \%$ en $0,02 \%$ ).

De conclusie die uit de uitgevoerde correlatietests kan worden getrokken, is dat de interne consistentie van de beantwoording van het betreffende deel van de enquête dermate is, dat hiermee de geloofwaardigheid van de eerder uitgevoerde betrouwbaarheidstests niet wordt aangetast.

Op basis van de uitgevoerde non-parametrische tests alsmede de correlatietests dient de hypothese zoals in paragraaf 1 gesteld, te worden verworpen. Het model van gegevenskenmerken uit het conceptual framework van de financial accounting volstaat ook voor de management accounting. In de management accounting worden ten aanzien van de in dit model onderscheiden gegevenskenmerken over het algemeen geen significant afwijkende belangrijkheidscoëfficiënten gehanteerd.

\section{Overige enquête-resultaten}

Het externe en interne berichtgevingssysteem bleek in de bedrijven waar de respondenten werkzaam zijn slechts in enkele gevallen van elkaar te verschillen. Derhalve valt grote overeenstemming te constateren tussen externe en interne accountingsystemen. De categorieën 4 en 5 (volledig afwijkend) vertegenwoordigden respectievelijk $12 \%$ en $2 \%$ en derhalve in totaal slechts $14 \%$ van de totale response op de betreffende vijfpuntsschaal. Deze resultaten vormen geen sluitend bewijs voor de bewering dat de praktijk van de management accounting wordt gedreven door een externe verslagleggingsmentaliteit, maar deze resultaten zijn toch een indicatie van de bereidheid interne berichtgevingssystemen op te offeren aan externe systemen (zie Porter et al, 1987:58).

Als belangrijkste redenen voor de gesignaleerde overeenstemming tussen de interne en de externe berichtgevingssystemen werden genoemd (1) efficiency (kosten) en (2) eenvoud. Hierbij is opvallend dat controllers eerder voor kosten kiezen dan accountants die meer voor eenvoud kiezen. De verschillen tussen het externe en interne berichtgevingssysteem concentreren zich met name in het (overige) bedrijfsleven (zie vraag 4A). Bij een meer internationaal georiënteerd bedrijf nemen de verschillen tussen beide berichtgevingssystemen toe. Volstrekte afwijking tussen beide systemen komt uitsluitend bij dit type bedrijven voor ( $4 \%$ van de onderzochte gevallen).

Wanneer het externe en interne berichtgevingssysteem van elkaar afwijken (vraag $7 \mathrm{C}$ ) vindt dit met name plaats op het terrein van (1) de waardering van duurzame materiële activa en (2) de winstbepaling. Van de 126 respondenten rapporteert in beide gevallen $17,5 \%$ deze afwijkingen. 


\section{MAB}

Ook voorzieningen worden relatief vaak extern anders behandeld dan intern (ruim 14\% van de onderzochte gevallen), duurzame immateriële activa worden vaak afwijkend gewaardeerd (ruim $11 \%$ ) terwijl intern in 1 op de 9 bedrijven wordt rekening gehouden met rente over het eigen vermogen (en dus met opportunity kosten). Voor externe doeleinden werd in $14 \%$ van de onderzochte gevallen een andere consolidatieprocedure gevolgd. Opvallend is de frequentie van het extern en intern afwijkend behandelen van voorzieningen in accountantskantoren: $7 \%$ van het totaal ten opzichte van het (overige) bedrijfsleven $6 \%{ }^{7}$ In geval van het internationaal georiënteerd bedrijf concentreren zich de verschillen tussen de externe en interne berichtgeving met name op afwijkende winstbepalingsstelsels. Typerend is dat in geval van een hoofdzakelijk nationaal opererend bedrijf de post voorzieningen in de externe respectievelijk interne berichtgeving relatief frequenter afwijkend wordt behandeld dan in geval van een internationaal opererend bedrijf (respectievelijk $10 \%$ en $4 \%$ van alle onderzochte gevallen). Een verklaring hiervoor kan gelegen zijn in het feit dat de in internationaal verband opgestelde standaards ten aanzien van voorzieningen minder rekbaar zijn dan de nationale wetgeving in dezen of dat via internationalisatie diversificatie van risico's kan worden bewerkstelligd.

Van de 124 respondenten gaf $60 \%$ aan dat er in de afgelopen 3 jaar in het interne berichtgevingssysteem belangrijke wijzigingen waren aangebracht. Hiermee wordt bevestigd dat de management accounting zich op dit moment in een soort stroomversnelling bevindt en wordt het belang benadrukt dat management accountants zich, meer dan vroeger, een creatief innoverende houding dienen aan te meten. Opvallend doch voor deze tijd niet verrassend is dat in de non-profit sector bijna $80 \%$ van de respondenten te kennen gaf dat belangrijke systeemaanpassingen in het interne berichtgevingssysteem waren doorgevoerd.

In de categorie '(overig) bedriffsleven' was de verhouding tussen 'systeemaanpassingen/geen systeemaanpassingen' bijna 2 hetgeen eveneens wijst op een zekere veranderingsgezindheid.Een internationaal werkterrein bleek geen extra accelerator te zijn voor systeemaanpassingen. In de groep 'internationaal opererende bedrijven' bleek echter ruim $70 \%$ van de bedrijven systeemaanpassingen te hebben aangebracht, in de groep 'nationaal opererende bedrijven' was dit ruim $50 \%$. De aard van de gesignaleerde aanpassingen was zeer divers en liep uiteen van het invoeren van voor- en nacalculaties, tot een aangepast transfer-prijssysteem tot het opnemen van nietfinanciële gegevens in het interne systeem. Een duidelijke relatie in de gerapporteerde systeemaanpassingen en de aard van het bedrijf c.q. de bedrijfsorintatie was niet te onderkennen.

Meer dan de helft van de respondenten verwacht in de toekomst nieuwe belangrijke aanpassingen in het interne berichtgevingssysteem. In het (overig) bedrijfsleven gaf ruim $60 \%$ van de respondenten werkzaam in deze sector aan dat aanpassingen worden verwacht, voor de non-profit sector was dit bijna $80 \%$ en ook de overheid scoort met bijna $80 \%$ zeer hoog. Bij verwachte belangrijke systeemaanpassingen bleek een internationaal karakter van een bedrijf eerder een rem op dan een stimulator voor systeemaanpassingen te zijn. De gerapporteerde aard van de verwachte aanpassingen was zeer uiteenlopend. De meest frequente verwachte aanpassingen liggen op het terrein van 'performance measurement'.

Bijna $80 \%$ van de 119 in dit verband ondervraagde accountants en controllers is van mening dat de huidige interne berichtgeving te wensen overlaat! Controllers zijn deze mening meer toegedaan dan accountants (bij de accountants is driekwart ontevreden, bij de controllers ruim 83\%). Typerend zijn hierbij de nonprofit en overheidssector. In beide sectoren zijn respectievelijk $90 \%$ en $100 \%$ van de respondenten van mening dat de bestaande interne berichtgevingssystemen niet naar wens functioneren. De ratio nationaal/internationaal ten aanzien van de ontevredenheid met bestaande interne berichtgevingssystemen bedroeg bijna $1 \frac{1}{2}$. In het algemeen bleek deze ontevredenheid op te lopen met de duur van het dienstverband (zie vraag 3 ). Dit zou kunnen wij- 
zen op 'voortschrijdende inzichten' maar ook op een toenemende 'resistance for change' in de organisatie naarmate een systeem gedurende langere tijd in gebruik is.

Wat betreft de wijze waarop interne berichtgevingssystemen zouden kunnen worden verbeterd, antwoordde $23 \%$ van de 57 respondenten dat dit zou kunnen door meer en beter opgeleide mensen in dienst te nemen. Bijna $20 \%$ gaf te kennen dat een verbetering zou kunnen plaatsvinden door meer voorspellende waarde aan de gegevens toe te voegen. Ander factoren die werden genoemd zijn snelheid van de gegevensverstrekking opvoeren $(12 \%)$, automatisering $(11 \%)$, het toevoegen van niet-financiële gegevens $(9 \%)$, het opvoeren van de betrokkenheid van het management c.q. de totale organisatie bij de management accounting, tot uitdrukking komend in onder andere een integrale informatieplanning $(7 \%)$, meer externe gerichtheid (concurrenten, strategie) $(7 \%)$, meer gerichtheid op kritieke succesfactoren $(7 \%)^{8}$ en het ontwikkelen van een 'early warning' element in het management accountingsysteem (4\%).

Van de 119 respondenten is de helft van mening dat een financieel feit met toekomstige effecten zoals een loonafspraak, in de boekhouding dan wel anderszins in de bedrijfsadministratie dient te worden verwerkt hetgeen dan ook in vrijwel de zelfde mate in de praktijk gebeurt (zie vraag 12). ${ }^{9}$ Een vierde van de respondenten dat een dergelijk feit wel zou willen verwerken, doet dit op dit moment evenwel nog niet. Het percentage controller-respondenten dat dergelijke feiten administratief zou willen verwerken, ligt duidelijk hoger dan het percentage accountant-respondenten dat een dergelijke verwerking zou willen voorstaan $(68 \%$ versus $41 \%)$. Meestal vindt de verwerking plaats in het budgetsysteem en (derhalve) extracomptabel. Van de respondenten die aangaven dat dergelijke feiten op dit moment niet in hun bedrijfsadministratie worden verwerkt, gaf het overgrote deel te kennen dat het door hen ook niet van belang werd geacht dergelijke gegevens in een boekhouding te verwerken.

\section{Samenvatting}

Hartman geeft aan dat de kwaliteit van de informatie meer is dan betrouwbaarheid alleen. Binnen de traditionele administratieve organisatie ligt het accent op deze betrouwbaarheid maar het waarborgen van enkele van de andere kenmerken is vaak veel belangrijker voor de voortgang van het primaire proces binnen de organisatie respectievelijk voor het nemen van de goede managementbeslissingen (Hartman, 1993:378). Hartman pleit in dit verband voor het vervangen van het vak administratieve organisatie $(A O)$ door een vak 'Organisatie van de Informatieverzorging' (OIV) waarbij optimale behandeling van gegevens uitgangspunt is zodat deze gegevens voor kwalitatief hoogstaande informatieverstrekking kunnen dienen. Het conceptual framework zoals dat binnen de financial accounting wordt gebruikt, kan mijns inziens ook te dien aanzien goede diensten bewijzen.

Interne berichtgevingssystemen bevinden zich duidelijk in een fase van overgang. Relatief veel bedrijven hebben hun systeem in de afgelopen drie jaar op belangrijke onderdelen aangepast en de verwachting is dat deze ontwikkeling zich in de nabije toekomst zal doorzetten. Veel heil wordt gezien in het verbeteren van de opleiding van financiële functionarissen en in het toevoegen van voorspellende waarde aan het management accountingsysteem. Wat dit laatste betreft biedt triple-entry accounting zoals voorgesteld door ljiri $(1982,1986,1989)$ en Blommaert $(1990$, 1991) goede mogelijkheden.

\section{Literatuur}

Accounting Standards Board (ASB), Exposure Draft-Statement of Principles, The Objective of Financial Statements and the Qualitative Characteristics of Financial Information, Accountancy, september 1991

Ahituv, N., en S. Neumann. Principles of information systems for management, 1986

Anthony, R.N., We don't have the accounting concepts we need, artikel in de bundel: Getting numbers you can trust. The new accounting. 1991.

Beek, A. en S. van Duin, Hoofdlijnen Bestuurlijke Informatievoorziening. 1993. 
Blommaert, A.M.M. en J.M.J. Blommaert, Drie-dimensionaal boekhouden deel I, Maandblad voor Bedrijfsadministratie en -Organisatie, maart 1990.

Blommaert, A.M.M. en J.M.J. Blommaert, Drie-dimensionaal boekhouden deel II, Maandblad voor Bedrijfsadministratie en -Organisatie, april 1990.

Blommaert, A.M.M., Management Accounting. Conceptual Framework and Triple-Entry Accounting, paper, EAA-congres Madrid, april 1991.

Bromwich, M., Managerial Accounting Definition and Scope - From a Managerial View, Management Accountant, september 1988, p. 26

Bromwich, M. en A. Bhimani, Management Accounting: Evolution not Revolution, Management Accounting, oktober 1989, pp. 5-6.

Eijkelberg, J., Triple-entry accounting, een experimentele casestudy, doctoraalscriptie, Rijksuniversiteit Limburg, 1992.

Ewalts, G., Van een kinematisch naar een kinetisch accountingmodel: een onderzoek naar de administratie van winstkrachten, doctoraalscriptie, Rijksuniversiteit Limburg, 1993.

Feltham, G.A., The Value of Information, The Acounting Review, oktober 1968.

Financial Accounting Standards Board, Objectives of Financia Reporting by Business Enterprises, Statement of Financial Accounting Concepts No.1, 1978, pp. 684-696.

Financial Accounting Standards Board, Qualitative Characteristics of Accounting Information, Statement of Financial Accounting Concepts No.2, 1980.

Financial Accounting Standards Board, Elements of Financial Statements of Business Enterprises, Statement of Financial Accounting Concepts No. 3, 1980.

Goldratt, E.M. en R.E. Fox, The Haystack syndrom, 1991.

Hartman, W., Typologie en mosselcultuur, De Accountant, februari 1993.

Hartog, P.A., A. Molenkamp en J.H.M. Otten, Kwaliteit van Administratieve Dienstverlening (Managen is integreren), 1992.

Hopper, T., L. Kirkham, R.W. Scapens en S. Turley, Does financial accounting dominate management accounting a research note, Management Accounting Research, 1992, 3 , pp. 307-311.

IFAC, Statements on International Management Accounting, handboek deel 2, hoofdstuk 12, pp. 13-15.

ljiri, Y., Triple-Entry Accounting and Income Momentum, American Accounting Association, Studies in Accounting Research No. 18, 1982.

ljiri, Y.. A Framework for Triple-Entry Bookkeeping, The Accounting Review, oktober 1986.

Ijiri, Y., Three Postulates of Momentum Accounting, Accounting Horizons, maart 1987.

Ijiri, Y., Momentum Accounting and Triple Entry Bookkeeping. Exploring the dynamic structure of Accounting Measurements, American Accounting Association, Studies in Accounting Research No. 31, 1989.

International Accounting Standards Committee (IASC), Framework for the Preparation and Presentation of Financial Statements, juli 1989

Johnson, H.T. en R.S. Kaplan, Relevance lost, The rise and Fall of Management Accounting, 1987.

Lewy, C.P., Management Control Regained, De financieel/economische beheersing van complexe organisaties - een integratie van theorie en praktijk, 1992.
Mednick, R., The future of auditing, a vision from the US, Maandblad voor Accountancy en Bedrijfseconomie, december 1992.

Meuwissen R., De meting en de omvang van accountantskantoren: een empirische studie, research memorandum, Rijksuniversiteit Limburg, 1992.

NERA (National Economic Research Associate), rapport: Competition in economic accounting, 1992.

Porter, G.L. en M.D. Akers, In Defense of Management Accounting, Management Accounting, november 1987, pp. 58-62.

Siegel, S. en N.J. Castellan jr., Nonparametric Statistics for the behavioral sciences, 1988.

Wallage Ph. en J.J. Tijhuis, Controller en registeraccountant; een sterk team?, Controllersvizier, 1992/1.

\section{Noten}

1 Met dank aan Prof. Dr. J.G. Kuijl RA voor zijn opmerkingen op een eerdere versie van dit artikel. Ook bedank ik Eric Olders voor zijn assistentie bij de statistische verwerking van de onderzoeksgegevens.

2 In bijlage 1 is voor wat betreft de gegevenskenmerken het conceptual framework zoals voorgesteld door het IASC (International Accounting Standards Committee) opgenomen. De modellen van de FASB (Financial Accounting Standards Board) c.q. ASB (Accounting Standards Board) wijken hiervan niet of nauwelijks af

3 Deze enquête-formulieren werden in het tijdschrift 'Controllersvizier' (losbladig) opgenomen. De redactie van Controllersvizier ben ik bijzonder erkentelijk voor haar vrijwillige medewerking in dezen.

4 Bij de interpretatie van deze gegevens dient te worden bedacht dat het soms onduidelijk kan zijn onder welke categorie van werkzaamheden bepaalde activiteiten vallen. Waartoe bijvoorbeeld is door de respondenten de advisering omtrent interne controleprocedures gerekend? Overigens bedroeg in 1988 het controle-aandeel in de totale omzet bij de grote Nederlandse accountantskantoren nog zo'n 65\% (Het Financieele Dagblad, mei 1989). Het feit dat dit aandeel dalende is (zie ook Meuwissen, 1992:15-17; NERA-rapport, 1992:59) wordt door de enquête-resultaten bevestigd.

5 Wellicht dat controllers nog in (te) sterk door accountantsculturen bepaalde omgevingen worden opgeleid.

6 Mijns inziens dient bijvoorbeeld het vak administratieve organisatie in een management accountants- c.q. controllersperspectief van andere inhoud te worden voorzien (in elk geval qua accenten) dan in een financial accountantsperspectief. 7 Gaat het hier om de verwerking van potentiële schadeclaims van ontevreden cliënten/gebruikers?

8 Deze factoren worden vaak als 'kritische' factoren aangeduid (zie bijvoorbeeld Hartog et al, 1992:56) hetgeen mijns inziens een onjuiste vertaling is van het woord 'critical' in 'critical success factors'. 'Critical' betekent hierbij 'beslissend' of 'van doorslaggevende betekenis' en derhalve 'kritiek'.

9 De interpretatie van vraag 12 leverde bij een aantal respondenten de nodige problemen op, met name ten aanzien van het onderscheid boekhouding/bedrijfsadministratie/management accounting en met betrekking tot een intracomptabele respectievelijk extracomptabele verwerking van prospectieve gegevens. Hier strookt het exploratieve karakter van de vragen niet met de gevolgde kwantitatieve onderzoekmethode. 


\section{Bijlage 1}

IASC-model

A hierarchy of

Accounting Qualities

Users of

Accounting Information

Decision Makers and their Characteristics (For Example, Understanding or Prior Knowledge)

Pervasive Constraint

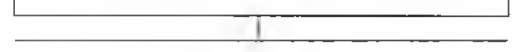

User-Specific Qualities

Benefits $>$ Costs

User-Specific Qualities

Primary Decision-

Specific Qualities

Ingredients of

Primary Qualities

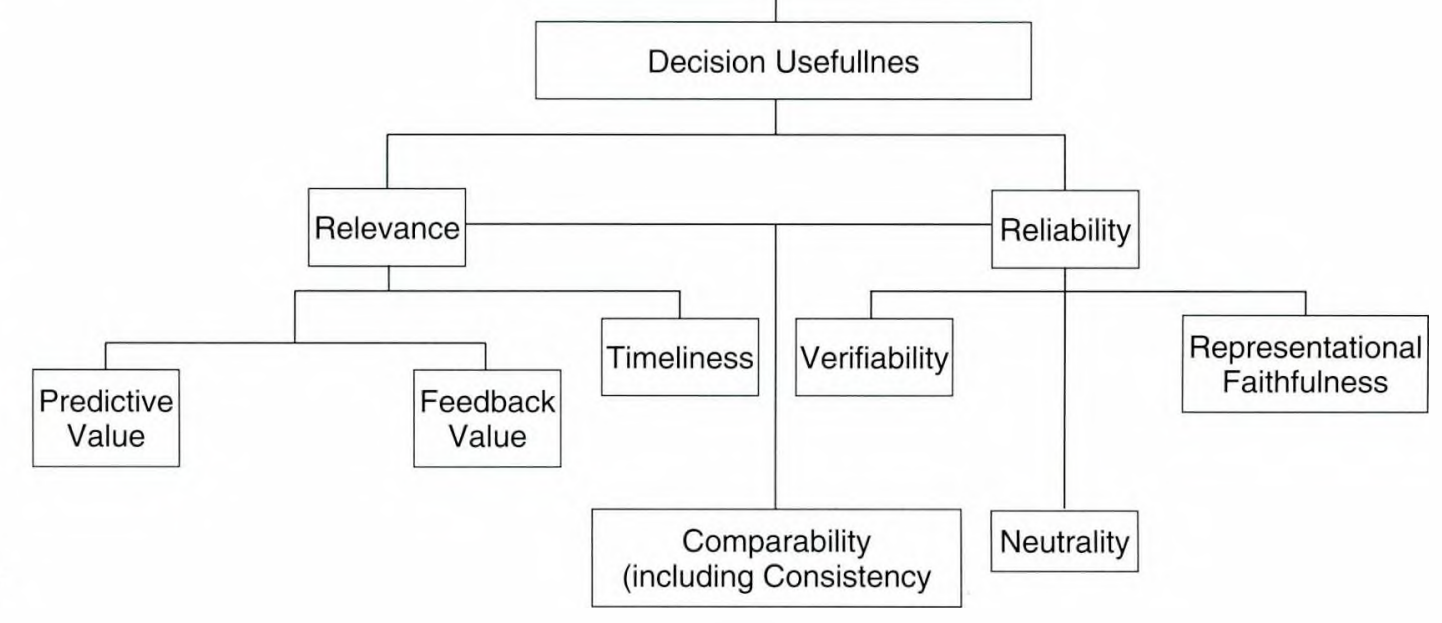

Secondary and

Interactive Qualities

including Consistency

Treshold for

Materiality

recognition

\section{Bijlage 2}

\section{ENQUETE}

\section{Over uw opleiding}

U kunt de letter van het van toepassing zijnde antwoord omcirkelen. Wilt u s.v.p. ook het jaar van afstuderen vermelden? In situatie d graag een nadere toelichting.

a Ik ben afgestudeerd in $19 \ldots$ als registeraccountant (RA) bij het NIvRA.

b Ik ben afgestudeerd in $19 \ldots$ als registeraccountant (RA) via een postdoctorale accountantsopleiding.

c Ik ben afgestudeerd in $19 \ldots$ als registercontroller (RC) via een postdoctorale controllersopleiding.

d Anders:

\section{Over uw functie}

Een extern accountant houdt zich gewoonlijk voornamelijk bezig met (jaarrekening-) controlewerkzaamheden, dat wil zeg- 
gen, controle van afgelegde verantwoording. Een intern accountant en een controller kunnen zich ook bezig houden met (interne) controlewerkzaamheden maar vaak beslaat hun werk meer dat van de advisering, dat wil zeggen, financieel-economische ondersteuning van beslissings- en uitvoeringsprocessen. Daarnaast bestaat de mogelijkheid dat $u$ als eindverantwoordelijke van een bepaalde afdeling leiding geeft aan een aantal medewerkers.

Hoe ligt de verhouding binnen deze werkzaamheden in uw functie?

a Qua tijdsbesteding is mijn huidige functie-inhoud:

controlewerkzaamheden advieswerkzaamheden (lijn-)management

$$
\text { ...\% ...\% ...\% }
$$

b In hoeverre is de verdeling van werkzaamheden zoals bedoeld onder a in de afgelopen 3 jaar voor u gewijzigd?

Drie jaar geleden was de verdeling van mijn werkzaamheden als volgt:

controlewerkzaamheden advieswerkzaamheden (lijn-)management

$$
\text { ...\% }
$$

$\%$

$\%$

c Ik houd mij bezig met andere werkzaamheden, te weten (eventueel een nadere verdeling aangeven)

\section{Over de duur van uw functieverband}

U kunt de letter van het van toepassing zijnde antwoord omcirkelen.

a In mijn huidige functie ben ik minder dan 1 jaar werkzaam.

b In mijn huidige functie ben ik langer dan 1 jaar maar minder dan 3 jaar werkzaam.

c In mijn huidige functie ben ik meer dan 3 jaar werkzaam.

\section{Over uw werkkring}

U kunt de letter van het van toepassing zijnde antwoord omcirkelen. In situatie Bb s.v.p. ook het betreffende land vermelden.
A Over de aard van uw bedrijf
a Ik ben werkzaam bij de overheid.
b Ik ben werkzaam op een accountantskantoor.
c Ik ben werkzaam in de non-profit sector.
d I $\mathrm{k}$ ben werkzaam in het (overige) bedrijfsleven.

\section{B Over de oriëntatie van uw bedrijf}

a Het bedrijf waar ik werk is hoofdzakelijk nationaal werkzaam, dat wil zeggen, $50 \%$ of meer van de omzet wordt in Nederland gerealiseerd.

b Het bedrijf waar ik werk heeft een sterke internationale oriëntatie, dat wil zeggen, $50 \%$ of meer van de omzet wordt in het buitenland gerealiseerd. Het buitenland dat in dit verband het meest bepalend is:

\section{Over de positionering van uw werk}

Voor zover uw functie accountingwerkzaamheden betreffen, tot welk terrein behoren dan deze activiteiten?

$F A=$ financial accounting (=externe berichting; denk aan de verslaglegging naar aandeelhouders, bankiers en fiscus).

$\mathrm{MA}=$ management accounting (=interne berichting; denk aan budgettering en kostprijsbepaling).

Onderstaande vijfpunts-schaal loopt van volledige oriëntatie op FA tot volledige oriëntatie op MA. Geeft u s.v.p. door het aankruisen van een hokje aan hoe uw accountingwerkzaamheden verdeeld zijn.

volledig FA

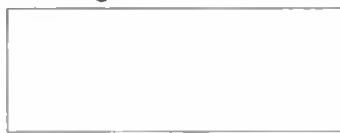

1 volledig MA

Eventuele toelichting 


\section{De functie van accounting in uw werk}

Voor zover u zelf accountingwerkzaamheden uitvoert, op welke functie zijn deze dan voornamelijk (meer dan $80 \%$ ) gericht? U kunt de letter van het van toepassing zijnde antwoord omcirkelen. In situatie d s.v.p. een nadere toelichting geven.

a Het verstrekken van gegevens t.b.v. de ondersteuning van te nemen beslissingen (planning).

b Het verstrekken van gegevens t.b.v. de beheersing van in uitvoer genomen beslissingen ('control').

c Het verstrekken van gegevens t.b.v. de verantwoording die over in het verleden genomen en uitgevoerde beslissingen dient te worden afgelegd.

d Anders:

\section{Het accountingsysteem in uw organisatie}

A

Het externe en interne berichtgevingssysteem (afgezien van het fiscale systeem) kunnen inhoudelijk aanzienlijk van elkaar verschillen (denk aan een afwijkend stelsel van winstbepaling, afwijkende waardering van vaste activa/voorraden, het doorberekenen van rente op eigen vermogen, en dergelijke). In welke mate verschillen het externe en interne berichtgevingssysteem in uw organisatie c.q. de organisatie(-s) die u controleert?

Onderstaande vijfpunts-schaal loopt van volledige overeenstemming tussen het externe en interne berichtgevingssysteem tot volstrekte afwijking tussen beide systemen. Geeft u s.v.p. door het aankruisen van een hokje aan in welke mate beide systemen van elkaar verschillen.

volledige

volstrekte

overeenstemming

afwijking

\begin{tabular}{|c|c|c|c|c|}
\hline & & & & \\
& & & \\
\hline
\end{tabular}

$B$

Indien voor $u$ van toepassing (hokje $1 / 2$ bij vraag $7 \mathrm{~A}$ )

Wat is naar uw mening de belangrijkste reden voor het gelijk houden van het externe en interne berichtgevingssysteem in uw organisatie c.q. de organisatie(-s) die u controleert?

C

Indien voor $u$ van toepassing (hokje $3 / 4 / 5$ bij vraag $7 \mathrm{~A}$ )

Op welke belangrijke accountingonderdelen wijken het externe en interne berichtgevingssysteem in uw organisatie c.q. in de organisatie(-s) die u controleert, af?

$\mathrm{U}$ kunt de letter van het van toepassing zijnde antwoord omcirkelen. Onder 8 en 9 is ruimte gelaten voor in uw ogen specifieke verschillen in beide systemen.

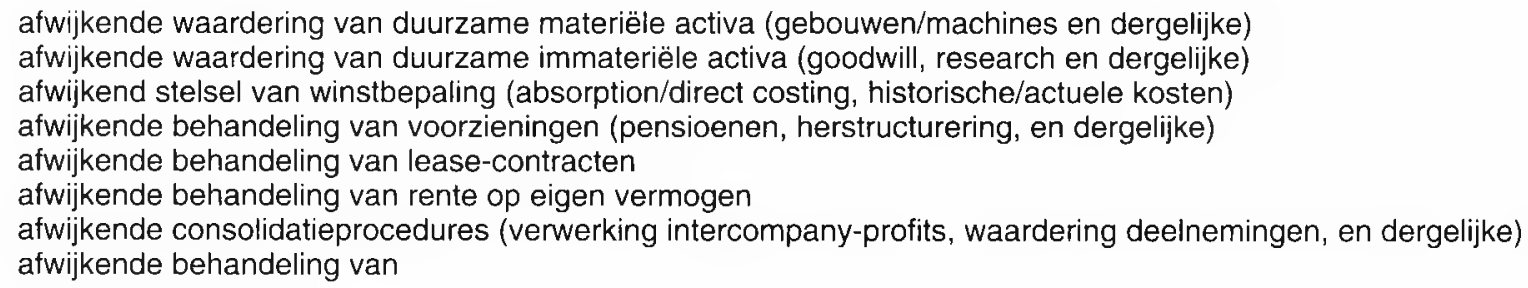

afwijkende behandeling van

D

Indien voor u van toepassing

Kunt $u$ kort aangeven waarom het externe en interne berichtgevingssysteem afwijken op de door $u$ onder $\mathrm{C}$ aangegeven onderdelen? 


\section{Uw ervaring met systeemaanpassingen}

In hoeverre hebben er, al dan niet onder uw leiding, de afgelopen drie jaar in de organisatie waar u thans werkt c.q. de organisatie(s) die u controleert belangrijke inhoudelijke aanpassingen in het interne berichtgevingssysteem plaatsgevonden? U kunt de letter van het van toepassing zijnde antwoord omcirkelen. In geval b graag een korte toelichting.

a Er hebben geen belangrijke systeemaanpassingen plaatsgevonden.

b Het interne berichtgevingssysteem is aangepast en wel als volgt (denk aan budgettering, kostprijssysteem, transferprijzen, stelsel van winstbepaling, waarderingssysteem):

\section{Uw verwachting ten aanzien van toekomstige systeemaanpassingen}

Op welke aspecten verwacht $u$ in de organisatie waarin $u$ thans werkt c.q. de organisatie(-s) die $u$ thans controleert in de komende drie jaar belangrijke aanpassingen van het interne berichtgevingssysteem? U kunt de letter van het van toepassing zijnde antwoord omcirkelen. In geval b graag een korte toelichting.

a I verwacht geen belangrijke aanpassingen.

b Ik verwacht belangrijke aanpassingen en wel als volgt:

\section{Uw mening over financiële informatie}

Ten aanzien van te verstrekken gegevens worden twee sleutelkenmerken onderscheiden: relevantie ('relevance') en betrouwbaarheid ('reliability'). Welk aspect acht $u$ in uw werk het meest belangrijk? Voor beide aspecten is een vijfpuntsschaal uitgezet die loopt van bijzonder belangrijk tot volstrekt onbelangrijk. Geeft u s.v.p. door het aankruisen van een hokje aan in welke mate $u$ het betreffende aspect voor uw eigen accountingwerkzaamheden belangrijk acht.

a

Relevantie

bijzonder

belangrijk

olstrekt

\begin{tabular}{|c|c|c|c|c|}
\hline & & & & \\
& & & \\
& & & & \\
\hline
\end{tabular}

b

bijzonder

Betrouwbaarheid

belangrijk

volstrekt

\begin{tabular}{ll}
\hline \\
\end{tabular}

1

2

3

4

5

Eventuele toelichting:

\section{Nogmaals uw mening over financiële informatie}

Hierna zijn een 7-tal informatiekarakteristieken onderscheiden. Hoe zoudt $u$, in het licht van uw huidige accountingwerkzaamheden, de belangrijkheid van elk aspect inschalen? Voor de beantwoording is voor elk kenmerk een vijfpunts-schaal uitgezet die loopt van zeer belangrijk tot volstrekt onbelangrijk. Geeft u s.v.p. door het aankruisen van een hokje aan hoe belangrijk $u$ elk aspect acht. Onder $h$, i en j kunt u eventuele door u belangrijk geachte (hier niet vermelde) aspecten toevoegen. 


\section{MAB}

bijzonder

volstrekt

belangrijk onbelangrijk

a

predictive value

(waarde t.b.v.

voorspellingen)

b

feed-back value

(waarde t.b.v.

beheersing)

c timeliness

(tijdigheid)

d neutrality

(onpartijdigheid)

e comparability/consistency

(vergelijkbaarheid/

consistentie)

f verifiability

(controleerbaarheid)

g representat. faithfulness

(representativiteit/

externe validiteit)

h eventuele aanvulling

i eventuele aanvulling

j eventuele aanvulling
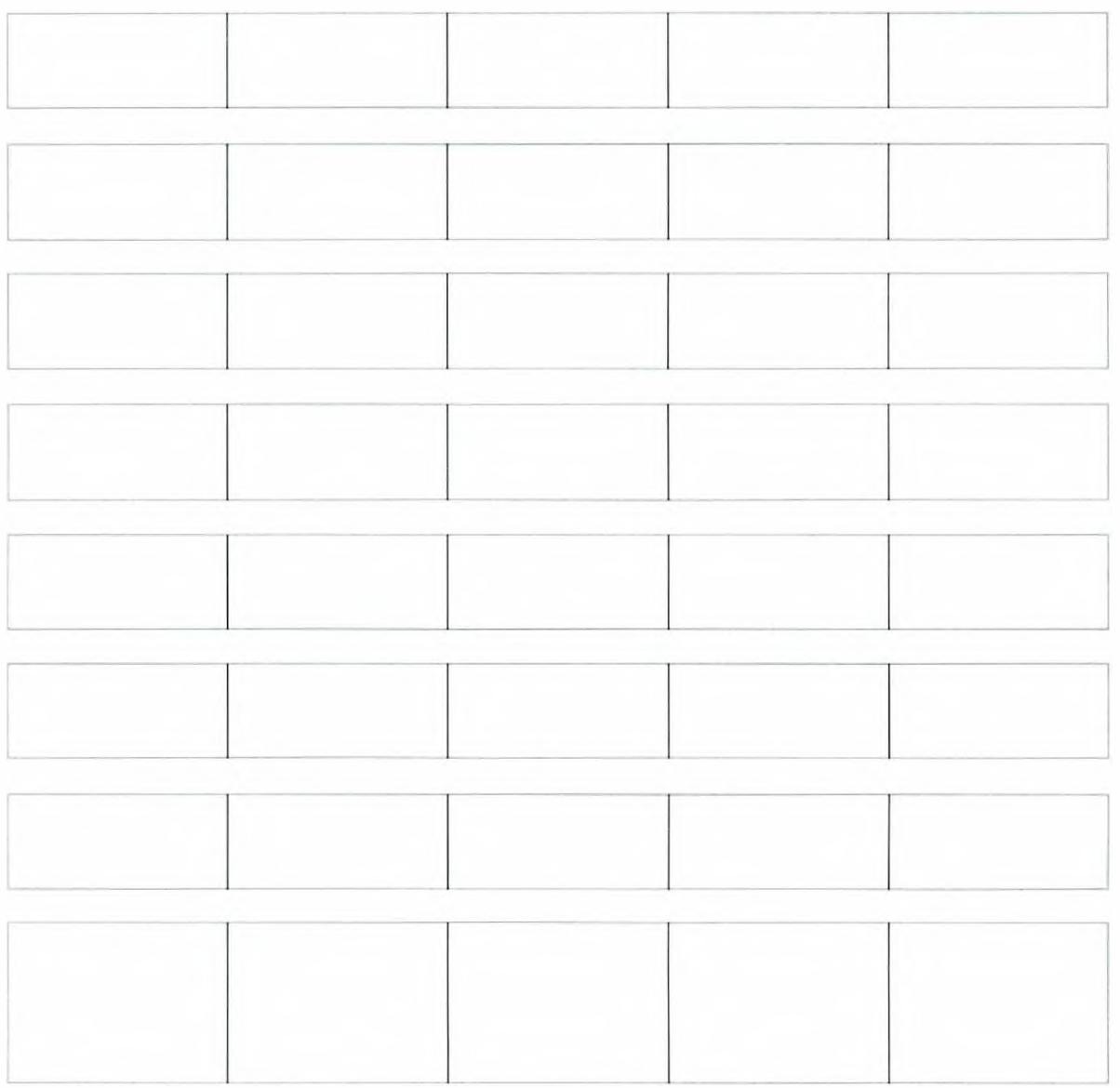

\section{Uw mening over financiële feiten ('accounting events')}

In een onderneming komt het management met het personeel voor de komende twee jaar een loonstijging overeen van $4 \%$ per jaar. $U$ heeft berekend dat met deze beslissing de loonkosten in totaal met $f 120$ a $f 125$ mln zullen stijgen.

A

Worden in uw organisatie c.q. de organisatie(-s) die u controleert de gevolgen van deze overeenkomst direct (dus afgezien van de hogere loonbetalingen die in de tijd zullen plaatsvinden) in de boekhouding dan wel anderszins in de bedrijfsadministratie verwerkt? $U$ kunt de letter van het van toepassing zijnde antwoord omcirkelen. Graag een nadere toelichting bij uw antwoord.

a Neen, omdat

b.1 Ja, omdat

b.2 Zo ja, hoe vindt deze verwerking plaats?

B

Bent $u$ algemeen van mening dat dergelijke feiten in een boekhouding verwerkt dienen worden? $U$ kunt de letter van het van toepassing zijnde antwoord omcirkelen. Graag een nadere toelichting bij uw antwoord.

1 Ja. omdat.

2 Neen, omdat 


\section{Uw mening over de evolutie van management accounting}

De kwaliteit van de huidige interne berichtgeving laat volgens sommigen nogal te wensen over. Bent u het met deze stelling eens? Graag een korte toelichting.

a Neen, want

b Ja, omdat

\section{Uw mening over de toekomst van management accounting}

Hoe zou naar uw mening de kwaliteit van het interne berichtgevingssysteem in uw organisatie c.q. de organisatie(-s) die u controleert, verbeterd kunnen worden?

\section{Bijlage 3}

Tabel 3: Gemiddelde scores van financial accountants ten opzichte van management accountants (inclusief controllers) op een aantal gegevenscriteria

\begin{tabular}{llll}
\hline aspect & financial accountants & $\begin{array}{c}\text { gemiddelde score } \\
\text { management accountants } \\
\text { (inclusief controllers) }\end{array}$ & $\begin{array}{l}\text { indicatie van de significantie } \\
\text { van verschillen in spreiding } \\
\text { (p-waarde) }\end{array}$ \\
\hline voorspellende waarde & 3,63 & 3,86 & $8,415 \%$ \\
feedback waarde & 4,27 & 4,04 & $13,61 \%$ \\
tijdigheid & 4,15 & 4,14 & $41,975 \%$ \\
neutraliteit & 3,35 & 3,65 & $21,35 \%$ \\
vergelijkbaarheid & 3,77 & 4,06 & $46,04 \%$ \\
controleerbaarheid & 3,65 & 3,59 & $1,12 \%$ \\
externe validiteit & 3,19 & 3,21 & $0,09 \%$ \\
\hline
\end{tabular}

